\title{
ANALISIS PORTOFOLIO PEMBIAYAAN DI PERBANKAN SYARIAH YANG MEMILIKI RISIKO PEMBIAYAAN TERKECIL (Studi Kasus Bank BNI Syariah)
}

\author{
Ani Suhartini \\ Program Studi S2 Keuangan Syariah, STIE Ahmad Dahlan Jakarta \\ Saiful Anwar \\ Program Studi S2 Keuangan Syariah, STIE Ahmad Dahlan Jakarta \\ E-mail: saiful.anwar@stiead.ac.id, saiful.anwar@stiead.ac.id
}

\begin{abstract}
ABSTRAK
Bank sebagai lembaga keuangan yang salah satu fungsinya menjadimoderator antara pihak yang memiliki dana dengan pihak yang membutuhkanpinjaman dana baik untuk usaha maupun konsumsi pribadi mengharuskan Bank untukdapat memaksimalkan pembiayaan dan tentunya meminimalisir risiko pembiayaan yangdapat timbul karena pemberian pembiayaan tersebut.Mengingat risiko yang dihadapi oleh Bank cukup besar dalam pemberian pembiayaan pada berbagai sektor ekonomi yang ada, maka sangat diharapkan pemberian masing-masing sektor ekomoni dapat optimal, dan pada akhirnya diharapkan memiliki risiko paling minimal pada masing-masing sektor ekonomi di Indonesia.
\end{abstract}

Kata Kunci: Analisis Portofolio Pembiayaan, Risiko Pembiayaan Terkecil. 


\section{PENDAHULUAN}

Perkembangan industri keuangan syariah secara informasi telah dimulai sebelum dikeluarkannya kerangka hukum formal sebagai landasan operasional perbankan di Indonesia. Beberapa badan usaha pembiayaan non bank telah didirikan sebelum tahun 1992 yang telah menerapkan konsep bagi hasil dalam kegiatan operasionalnya. Hal tersebut menunjukkan kebutuhan masyarakat akan hadirnya institusi-institusi keuangan yang dapat memberikan jasa keuangan yang sesuai dengan syariah.

Pada dasarnya setiap bank perlu diregulasi karena kebutuhan untuk meregulasi bank sebagai institusi bermula dari adanya risiko yang melekat (inherent) pada system perbankan, karena itu kegagalan suatu bank (baik kegagalan sebagian maupun seluruhnya) dapat menimbulkan dampak terhadap perekonomian secara menyeluruh dan hal ini disebut dengan risiko sistemik (Badan Sertifikasi Manajemen Risiko, 2007).

Risiko sistemik adalah risiko di mana kegagalan sebuah bank dapat menimbulkan dampak yang menghancurkan perekonomian secara besarbesaran dan bukan hanya dampak berupa kerugian yang secara langsung dihadapi oleh karyawan, nasabah, dan pemegang saham (Badan Sertifikasi Manajemen Risiko, 2007). Mengingat risiko yang dihadapi oleh Bank cukup besar dalam pemberian pembiayaan pada berbagai sektor ekonomi yang ada, maka sangat diharapkan pemberian masing-masing sektor ekomoni dapat optimal, dan pada akhirnya diharapkan memiliki risiko paling minimal. Bank dalam memberikan pembiayaannya terbagi dalam beberapa sektor ekonomi dan besarnya porsi pemberian pembiayaan dapat terlihat dari posisi pembiayaan masing-masing sektor ekonomi di bawah ini. 


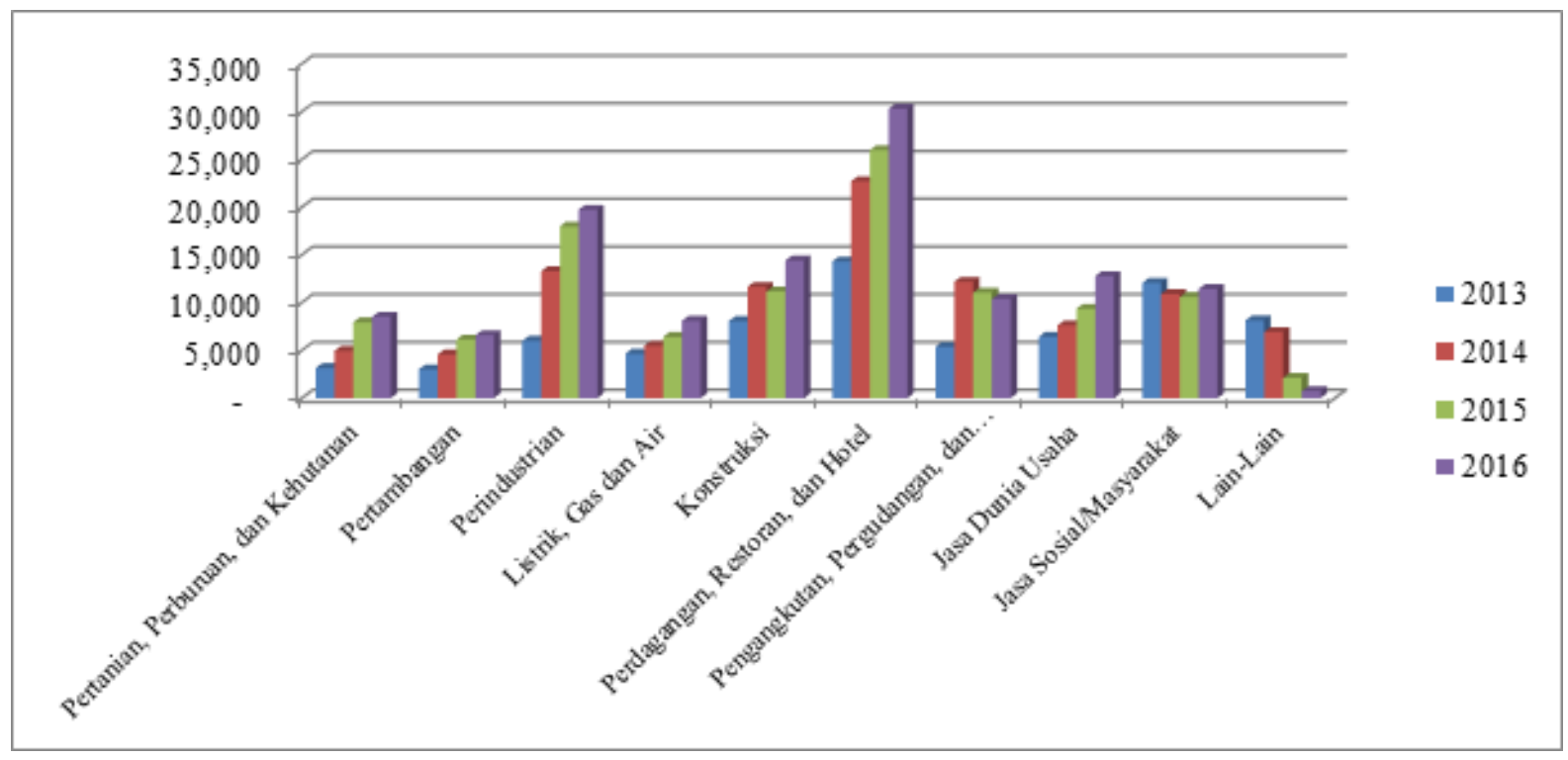

Sumber : Data OJK Statistik Perbankan Syariah Desember 2016

Gambar 1. Struktur Pembiayaan Bank Syariah Berdasarkan Sektor Ekonomi

Sektor perbankan melakukan pembagian sektor industri dalam memberikan pembiayannya, hal ini lebih dikenal sebagai portofolio pembiayaan perbankan. Setiap bank berhak menentukan pemberian pembiayaan yang akan diberikan pada sektor ekonomi tertentu sesuai dengan risiko yang telah dipertimbangkan oleh masing-masing manajemen perbankan itu sendiri, tentu dengan tetap mematuhi aturan yang telah ditetapkan oleh bank sentral, Bank Indonesia. Penyebaran portofolio yang dilakukan hampir seluruh bank sampai saat ini masih tetap banyak menimbulkan risiko yang tinggi, meskipun masing-masing perbankan telah memilih sektor ekonomi apa yang akan diberikan pembiayaan dan kemungkinan memiliki risiko default paling kecil, namun tetap saja hal itu belum dapat diminimalisasi dan masih menjadi tantangan untuk dapat meminimalisasi risiko dan mengelola risiko dengan baik.

Bank sebagai lembaga keuangan yang salah satu fungsinya menjadi perantara antara pihak yang memiliki dana dengan pihak yang membutuhkan pinjaman dana baik untuk usaha maupun konsumsi pribadi mengharuskan Bank untuk dapat memaksimalkan pembiayaan dan tentunya meminimalisir risiko pembiayaan yang dapat timbul karena 
pemberian pembiayaan tersebut, dimana FDR (Financing to Deposit Ratio) diusahakan maksimum, namun risiko pembiayaan harus ditekan.

FDR ini menjadi salah satu rasio likuiditas bank yang berjangka waktu agak panjang. Berdasarkan pengertian dari para ahli di atas, maka dapat disimpulkan bahwa Financing to Deposit Ratio (FDR) adalah rasio yang menggambarkan tingkat kemampuan bank syariah dalam mengembalikan dana kepada pihak ketiga melalui keuntungan yang diperoleh dari pembiayaan Mudharabah.

Sesuai dengan ketentuan Bank Indonesia bahwa rasio FDR minimal $80 \%$ dan tidak boleh melebihi $110 \%$. Dengan rasio FDR diantara tingkatan tersebut menandakan bahwa bank syariah menjalankan fungsi intermediasi dengan baik. Baiknya bank mampu menjaga nilai FDR hanya diantara $80 \%$ hingga $90 \%$. Dengan FDR $100 \%$ atau $110 \%$ menandakan bank mampu menyalurkan dana melebihi batas DPK yang dimiliki, dengan begitu tingkat perolehan keuntungan atau bagi hasil yang diterima bank akan semakin banyak. Tetapi semakin tinggi rasio ini mempengaruhi likuiditas bank karena nantinya bank tidak memiliki cukup cadangan dana untuk memenuhi permintaan kebutuhan dana masyarakat.

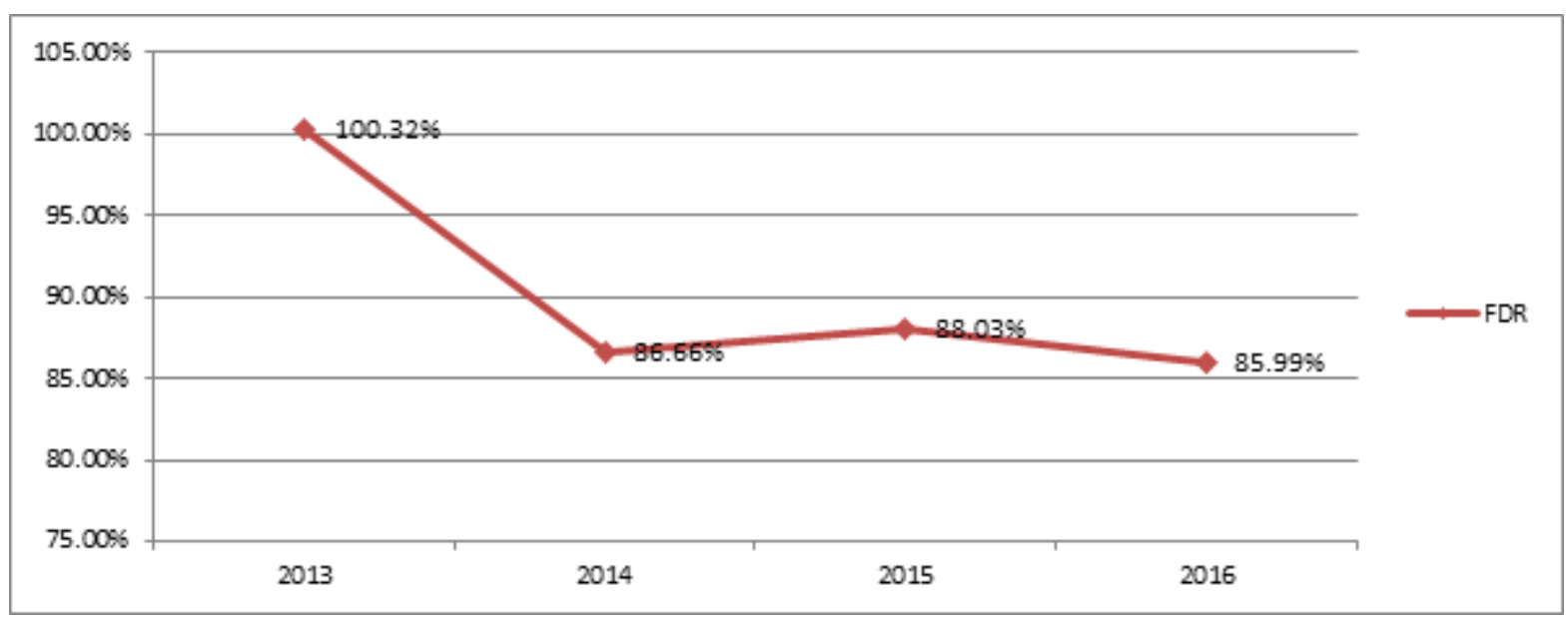

Sumber: Data OJK Statistik Perbankan Syariah Periode Desember 2016

Gambar 2. Financing Deposit Ratio Perbankan Syariah 
Selain tingkat FDR, untuk mengetahui kemampuan bank menjalankan fungsi intermediasi secara baik yaitu dengan mengetahui NPF (Non Performing Financing).Non Performing Financing atau pembiayaan bermasalah atau dalam bankkonvensional biasa disebut dengan Non Performing Loan (NPL) adalah suatupembiayaan yang mengalami masalah dalam pengembaliannya bisa dikarenakanfaktor eksternal pihak nasabah maupun internal dari bank itu sendiri (Siamat, 2005). Nilai FDR yang cukup tinggi ( $>80 \%$ ) akan berdampak pada tingkat NPF akan tinggi pula. Sebaliknya apabila nilai FDR menurun maka tingkat NPF juga ikut menurun. Hal ini digambarkan melalui grafik NPF perbankan Syariah di bawah ini.

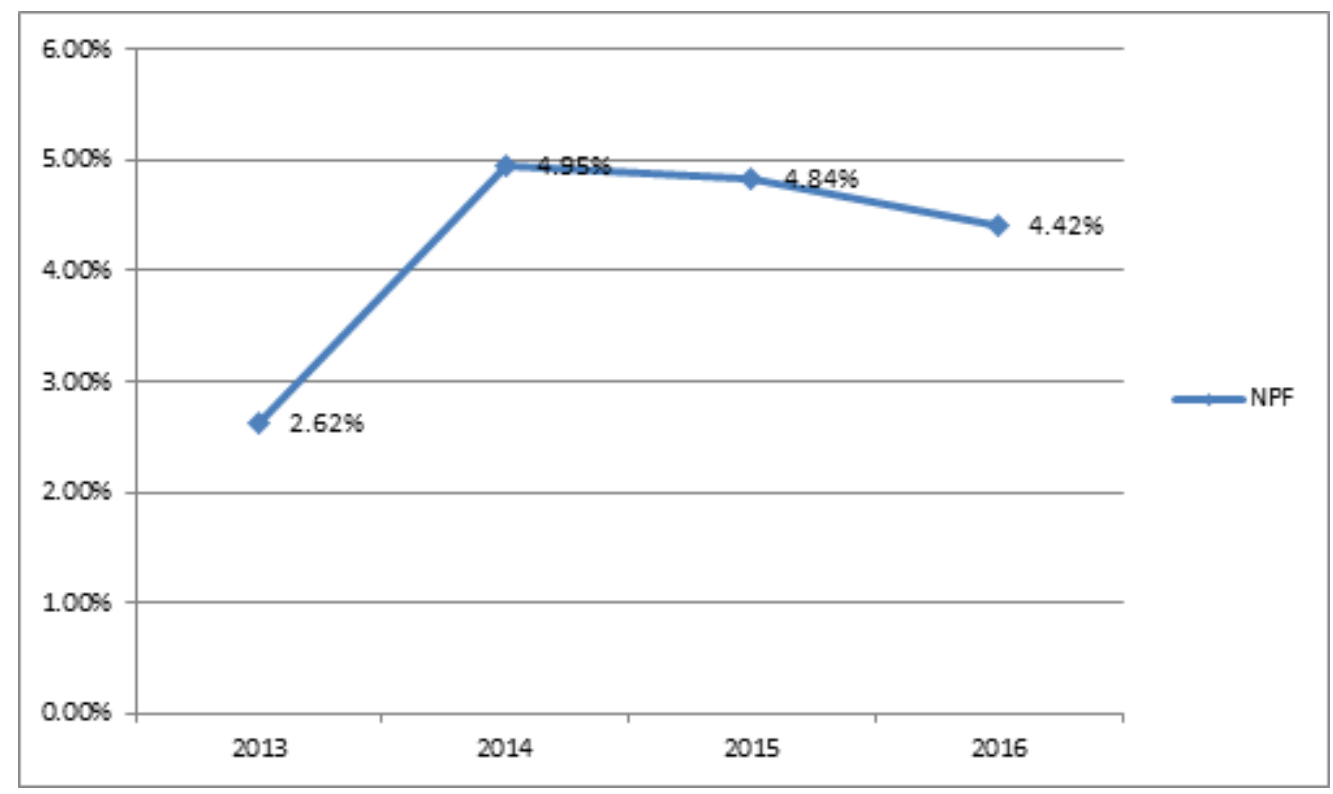

Sumber : Data OJK Statistik Perbankan Syariah Desember 2016

Gambar 3. Non Performing Loan Perbankan Syariah

Dari tabel NPF terlihat bahwa porsi pembiayaan setiap kategori perbankan syariah di Indonesia berbeda cukup siginifikan setiap kategorinya. Kondisi seperti ini tentu akan mempengaruhi Non Performing Financing (NPF)dan Financing to Deposit Ratio (FDR) perbankan syariah terkait. Apabila pembiayaan yang diberikan oleh setiap perbankan syariah 
dapat terjaga kualitas pembiayaannya, maka Non Performing Financing (NPF) dapat ditekan dan Financing to Deposit Ratio (FDR) dapat digunakan seoptimal mungkin. Posisi pembiayaan yang dimiliki oleh masing-masing kategori perbankan syariah di atas belum tentu merupakan posisi pembiayaan yang optimal yang telah diberikan oleh perbankan syariah sebagai alokasi portofolio pembiayaannya, terlebih lagi Non Performing Financing (NPF)dari setiap sektor ekonomi dan setiap kategori bank berbeda, untuk itulah dengan mengetahui posisi yang optimal dari masing-masing posisi pembiayaan tersebut, diharapkan dapat mengurangi kemungkinan risiko pembiayaan yang dapat terjadi.

Metode Markowitz yang diperkenalkan oleh Profesor Harry Markowitz dapat mengubah pandangan kaum investor mengenai risiko dengan jalan memperkenalkan konsep risiko secara kuantitatif.Strategi diversifikasi Markowitz terutama berhubungan dengan tingkat kovarians antara pengembalian aktiva dalam portofolio. Kontribusi utama dari jenis diversifikasi ini adalah formulasi risiko aktiva dalam hal portofolio aktiva, bukan risiko aktiva secara sendiri-sendiri. Diversifikasi Markowitz berusaha menggabungkan aktiva-aktiva dalam portofolio dengan pengembalian yang memiliki korelasi positif kurang dari sempurna, dengan tujuan mengurangi risiko portofolio (varians) tanpa mengurangi pengembalian (Fabozzi, 1999). Metode Markowitz ini dapat digunakan untuk menentukan risiko terkecil dari suatu portofolio, tidak hanya saham, namun dapat diterapkan juga pada posisi pembiayaan, dan hal ini merupakan keunggulan dari metode Markowitz.

Penelitian hanya akan dibatasi pada risiko pembiayaan karena risiko pembiayaan merupakan risiko yang paling dominan dalam aktivitas perbankan khususnya perbankan syariah, terutama berkaitan dengan pemberian pembiayaan yang dilakukan oleh Bank Syariah. Selain itu risiko pembiayaan merupakan satu-satunya risiko yang dirasa perlu diperhatikan dalam regulasi perbankan, Basel I, dimana The Basel Committee on Banking Supervision untuk pertama kalinya menawarkan suatu metodologi standar perhitungan jumlah modal berbasis risiko yang 

Risiko Pembiayaan Terkecil (Studi Kasus Bank BNI Syariah)

harus dimiliki sebuah bank dengan menerbitkan Basel CapitalAccord I tahun 1988 dan dalam Basel I tersebut hanya memperhitungkan mengenai masalah risiko pembiayaan (Badan Sertifikasi Manajemen Risiko, 2007). Itulah sebabnya penelitian lebih mengutamakan membahas mengenai risiko pembiayaan. Penelitian yang dilakukan juga akan dibatasi hanya dalam kurun waktu 2010-2015, kondisi perekonomian di Indonesia sering kali dalam kondisi mudah dipengaruhi oleh faktor-faktor eksternal baik dalam negeri maupun mancanegara setelah krisis moneter tahun 1998, misalnya kondisi politik, hukum, pemerintahan, dsb.

Meskipun sektor perbankan telah berusaha untuk meminimalisasi risiko yang dapat timbul atas pembiayaan yang diberikan kepada para pemohon pembiayaan, dan telah dilakukan penyebaran risiko dengan pembagian pembiayaan pada sektor industri yang bermacam-macam, namun nampaknya risiko yang muncul masih banyak dan tidak jarang selama ini hal tersebut dianggap suatu yang wajar dalam pemberian risiko. Penyebaran portofolio pembiayaan yang telah dilakukan oleh setiap perbankan, ternyata masih menimbulkan risiko yang cukup besar dan hal ini terlihat dari angka NonPerfoming Financing (NPF) yang masih tinggi. Seharusnya dengan mengetahui kombinasi sektor ekonomi yang memiliki risiko default terkecil, maka angka NPFdapat dikendalikan dan sektor ekonomi dapat berkembang dengan baik dan pada akhirnya profit yang diperoleh semakin meningkat baik untuk masing-masing perbankan syariah dan masyarakat pada umumnya.

\section{LANDASAN TEORI}

\subsection{Risiko}

Risiko dalam berbagai bentuk dan sumbernya merupakan komponen yang tak terpisahkan dari setiap aktivitas. Hal ini dikarenakan masa depan merupakan sesuatu yang sangat sulit diprediksi. Tidak ada seorang pun didunia ini yang tahu dengan pasti apa yang akan terjadi dimasa depan, bahkan mungkin satu detik kedepan. Selalu ada elemen ketidak pastian yang menimbulkan risiko (Dradjad H. Wibowo, dalam Masud Ali, 2006;xix) 
Adapun risiko-risiko yang dihadapi oleh perbankan dalam kegiatan operasionalnya, menurut H. Masud Ali (2006:19) adalah sebagai berikut:

a. Risiko Pasar (market risk)

Yang dimasud dengan risiko pasar adalah risko kerugian yang terjadi pada portofolio yang dimiliki oleh bank akibat adanya pergerakan variabel pasar (adverse moment) berupa suku bunga dan nilai tukar.

b. Risiko Kredit/Pembiayaan (credit risk)

Risiko kredit atau pembiayaan adalah risiko dari kemungkinan terjadinya kerugian bank sebagai akibat dari tidak dilunasinya kembali kredit/pembiayaan yang diberikan bank kepada debitur atau counterparty lainnya (Masud, 2006: 27)

c. Risiko Operasional (operational risk)

Risiko operasional (operational risk) adalah risiko terjadinya kerugian bagi bank yang diakibatkan oleh ketidakcakapan atau kegagalan proses dalam memanajemen bank, sumber daya manusia, dan sistem. Risiko kerugian tersebut dapat pula terjadi sebagai akibat dari faktor-faktor diluar bank.

\subsection{Risiko Pembiayaan}

Risiko ini mengacu pada potensi kerugian yang dihadapi bank ketika pembiayaan yang diberikan kepada debitur macet. Dimana debitur tidak mampu memenuhi kewajiban mengembalikan modal yang diberikan oleh bank. Selain pengembalian modal, risiko ini juga mencakup ketidakmampuan debitur menyerahkan porsi keuntungan yang seharusnya diperoleh oleh bank yang telah disepakati diawal. Konsekuensi penggunaan definisi ini adalah risiko pembiayaan hanya berlaku untuk akad berbasis utang, seperti qardhul hasan, jual beli muajjal dan jual beli salam. Debitur melakukan pembiayaan menggunakan skema akad-akad tersebut, diwajibkan untuk membayar kembali kepada bank sesuai termin yang telah disepakati. Kegagalan debitur melunasi kewajibannya dianggap sebagai kondisi gagal bayar, yaitu gagal dalam membayar cicilan pokok maupun porsi keuntungan. 


\subsection{Manajemen Risiko}

Manajemen risiko dalam bank islam mempunyai karakteristik berbeda dengan bank konvensional, terutama karena adanya jenis-jenis risiko yang khas melekat hanya pada bank-bank yang beropersi secara syariah. Dengan kata lain, perbedaan mendasar bank islam dan bank konvensional bukan terletak pada bagaimana cara mengukur (how to measure), meliankan pada apa yang dinilai (what to measure). Perbedaan tersebut akan tampak terlihat dalam proses manajemen risiko operasional bank islam yang meliputi identifikasi risiko, penilaian risiko, antisipasi risiko, dan monitoring risiko. ( Adiwarman : 2006:256)

Sebagai lembaga intermediary dan seiring dengan situasi lingkungan eksternal dan internal perbankan yang mengalami perkembangan yang pesat, perbankan pada umumnya dan perbakan syariah pada khususnya akan selalu berhadapan dengan berbagai jenis risiko dengan tingkat kompleksitas yang beragam dan melekat pada kegiatan usahanya.

Risiko-risiko tersebut tidak dapat dihindari, tetapi dapat dikelola dan dikendalikan. Oleh karena itu perbankan dan bank syariah khususnya memerlukan serangkaian prosedur dan metodologi yang dapat digunakan untuk mengidentifikasi, mengukur, memantau, dan mengendalikan risiko yang timbul dari kegiatan usahanya (Adiwarman, 2006: 255). Dalam pelaksanaannya, proses identifikasi, pengukuran, pemantauan, dan pengendali risiko

Menurut PBI (Peraturan Bank Indonesia) No. 5/8/PBI/2003 tentang Penerapan Manajemen Risiko Bagi Bank Umum, dinyatakan bahwa proses Manajemen Risiko Bank sekurang-kurangnya mencakup pendekatan pengukuran dan penilaian risiko, struktur limit dan pedoman serta parameter pengelolaan risiko, sistim informasi manajemen dan pelaporannya, serta evaluasi dan kaji ulang manajemen (Edatna, 2008). 


\subsection{Risiko-Risiko Yang Dihadapi Bank Syariah}

Bank syariah juga harus menghadapi risiko-risiko lain yang unik (khas). Risiko unik ini muncul karena isi neraca bank syariah yang berbeda dengan bank konvensional. Dalam hal ini pola bagi hasil (profit and loss sharing) yang dilakukan bank syari'ah menambah kemungkinan munculnya risiko-risiko lain. Seperti withdrawal risk, fiduciary risk, dan displaced commercial risk. Dimana:

a) Withdrawal risk merupakan bagian dari spektrum risiko bisnis. Risiko ini sebagian besar dihasilkan dari tekanan kompetitif yang dihadapi bank syariah dari bank konvesional sebagai counterpart-nya. Bank syariah dapat terkena withdrawal risk (risiko penarikan dana) disebabkan oleh deposan bila keuntungan yang mereka terima lebih rendah dari tingkat return yang diberikan oleh rival kompetitor-nya.

b) Fiduciary risk sebagai risiko yang secara hukum bertanggung jawab atas pelanggaran kontrak investasi baik ketidaksesuaiannya dengan ketentuan syariah atau salah kelola (mismanagement) terhadap dana investor.

c) Displaced commercial risk adalah transfer risiko yang berhubungan dengan simpanan kepada pemegang ekuitas. Risiko ini bisa muncul ketika bank berada di bawah tekanan untuk mendapatkan profit, namun bank justru harus memberikan sebagian profitnya kepada deposan akibat rendahnya tingkat return .

\subsection{Dampak Dari Risiko Yang Dihadapi Bank Syariah}

Sebagai dampak terjadinya risiko kerugian keuangan langsung, kerugian akibat risiko (risk loss) pada suatu bank dapat berdampak pada pemangku kepentingan (stakeholders) bank, yaitu pemegang saham, karyawan, dan nasabah, serta berdampak juga kepada perekonomian secara umum.

Pengaruh risk loss pada pemegang sahaman karyawan adalah langsung, sementara pengaruh terhadap nasabah dan perekonomian 
Ani Suhartini \& Saiful Anwar_Analisis Portofolio Pembiayaan Di Perbankan Syariah Yang Memiliki Risiko Pembiayaan Terkecil (Studi Kasus Bank BNI Syariah)

tidak langsung. Berikut akan diuraikan dampak potensial terhadap stakeholders dan ekonomi.

\subsection{Manajemen Risiko Pembiayaan Pada Bank Syariah}

Pengertian pembiayaan adalah penyediaan uang atau tagihan yang dapat dipersamakan dengan itu, berdasarkan persetujuan atau kesepakatan antara bank dengan pihak lain yang mewajibkan pihak yang dibiayai untuk mengembalikan uang atau tagihan tersebut setelah jangka waktu tertentu dengan imbalan atau bagi hasil.

Risiko Kredit atau pembiayaan adalah risiko kerugian yang diderita bank, terkait dengan kemungkinan bahwa pada saat jatuh tempo, counterparty-nya gagal memenuhi kewajiban-kewajibannya kepada bank. Risiko pembiayaan muncul jika bank tidak bisa memperoleh kembali cicilan pokok dan/atau bunga dari pinjaman yang diberikannya atau investasi yang sedang dilakukannya. Penyebab utamanya terjadinya risiko pembiayaan adalah terlalu mudahnya bank memberikan pinjaman atau melakukan investasi karena terlalu dituntut untuk memanfaatkan kelebihan likuiditas, sehingga penilaian kredit kurang cermat dalam mengantisipasi berbagai kemungkinan risiko usaha yang dibiayainya.

\subsection{Basel Accord I-II}

Basel Committee on Banking Supervision (BCBS) didirikan tahun 1975 sebagai penggerak harmonisasi dalam regulasi pengawasan bank pada tingkat internasional. Kecukupan modal merupakan fokus utama komite dan standar Bank International Settlement (BIS) diimplementasikan secara luas. Standar ini dimaksudkan untuk memperkuat sistem keuangan internasional dan mengurangi distorsi kondisi normal perdagangan.

\subsection{Portofolio Pembiayaan}

Teori Portofolio diartikan sebagai teori yang mengklasifikasikan pembagian portofolio guna meminimalisasi risiko dan memperoleh return yang tinggi. Selain itu teori portofolio diartikan pula sebagai studi tentang 
seorang investor individual mencapai pengembalian maksimum yang diharapkan dari portofolio yang berbeda-beda di mana masing-masing mempunyai tingkat risiko tertentu.

Di Indonesia, pembiayaan perbankan disalurkan pada 10 (sepuluh) sektor ekonomi sebagaimana yang didasarkan atas International Standard Industrial Classification of All Economic Activities (ISIC). Sepuluh sector tersebut adalah sebagai berikut (Laporan OJK):

a. Pertanian, Perburuan dan Sarana Pertanian

b. Pertambangan

c. Perindustrian

d. Listrik, Gas, dan Air

e. Konstruksi

f. Perdagangan, Restoran, dan Hotel

g. Pengangkutan, Pergudangan

h. Jasa Dunia Usaha

i. Jasa Sosial/Masyarakat

j. Lain-lain

\subsection{Markowitz Model}

Pendekatan Model Markowitz menekan aspek diversifikasi untuk mengoptimal keuntungan investasi dengan cara yang disebut pembentukkan portofolio yang efisien, yang memenuhi kriteria portofolio yang menawarkan tingkat keuntungan yang lebih besar dengan tingkat keuntungan yang sama dan portofolio yang menawarkan risiko lebih kecil dengan tingkat keuntungan sama.

Diversifikasi yang disarankan oleh Markowitz mengacu pada pembentukan portofolio yang memiliki tingkat pengembalian tertinggi pada tingkat risiko tertentu. Portofolio semacam itu disebut Markowitz Efficient Portofolio (MEP).

Data yang akan dihitung dalam Markowitz Efficient Portofolio (MEP) adalah nilai standart deviasinya sebagai cerminan risiko menurut penjabaran teori portofolio Markowitz, hasil yang ingin dicapai pada 
pembahasan pendekatan model Markowitz adalah menciptakan metode grafik yang diperlukan untuk mengidentifikasi saham-saham yang memiliki nilai secara absolut dan secara relatif lebih kecil (saham-saham berisiko rendah), yang mana secara karakteristik memungkinkan model CAPM untuk mendukung proses secara selektif dan menghasilkan model peramalan kuantitatif yang diharapkan.

Tabel 1. Ringkasan Penelitian Terdahulu

\begin{tabular}{|c|c|c|c|c|}
\hline No & Peneliti & Judul & Alat Analisis & Hasil \\
\hline 1 & $\begin{array}{l}\text { David Saunders, Costas Xiouros, } \\
\text { Stavros A. Zenios }\end{array}$ & $\begin{array}{l}\text { Credit Risk Optimization Using } \\
\text { Factor Models }\end{array}$ & $\begin{array}{l}\text { Expected Return and } \\
\text { Credit Risk }\end{array}$ & Optimal Portfolio \\
\hline 2 & $\begin{array}{l}\text { Bruce L. Jacobs, Kenneth, Harry } \\
\text { Markowitz (2003) }\end{array}$ & $\begin{array}{l}\text { Portfolio Optimization with Factors, } \\
\text { Scenarios, and Realistic Short } \\
\text { Position }\end{array}$ & $\begin{array}{l}\text { Mean Varians, } \\
\text { Eficient Frontiers }\end{array}$ & Optimal Portofolio \\
\hline 3 & $\begin{array}{l}\text { Allison Beste, Dennis Leventhal, } \\
\text { Jared Wiliams, Dr. Qin Lu (2002) }\end{array}$ & $\begin{array}{l}\text { The Markowitz Model: Selecting an } \\
\text { Efficient Investment Portfolio }\end{array}$ & $\begin{array}{l}\text { Titik Tunggal (Single } \\
\text { Point) }\end{array}$ & Optimal Portofolio \\
\hline 4 & $\begin{array}{l}\text { R. Agus Sartono, Sri Zulaihati } \\
(1998)\end{array}$ & \begin{tabular}{|l} 
Rasionalitas Investor Terhadap \\
Pemilihan Saham dan Penentuan \\
Portofolio Optimal dengan Model \\
Indeks Tunggal di BEJ \\
\end{tabular} & Model Index Tunggal & Optimal Portofolio \\
\hline 5 & Harry Markowitz (1959) & Portfolio Selection & $\begin{array}{l}\text { Expected \& } \\
\text { Unexpected Return }\end{array}$ & Optimal Portofolio \\
\hline 6 & Nurlianti Candradewi, SIP (20080 & $\begin{array}{l}\text { Analisis Posisi Kredit Per Sektor } \\
\text { Ekonomi Pada Perbankan di } \\
\text { Indonesia Yang Memiliki Risiko } \\
\text { Kredit Terkecil }\end{array}$ & Analisis Markowitz & $\begin{array}{l}\text { Sektor Ekonomi Listrik, Air, Gas } \\
\text { Cukup Mendominasi Pada Beberapa } \\
\text { Kategori Perbankan di Indonesia } \\
\text { (Bank Persero, BPD, Bank Swasta } \\
\text { Nasional, Bank Swasta Asing) }\end{array}$ \\
\hline
\end{tabular}

Sumber: Dari jurnal masing-masing peneliti

Berdasarkan latar belakang, perumusan masalah, tujuan penelitian, landasan teori dan penelitian terdahulu yang digunakansebagai acuan dalam penelitian ini, maka kerangka pemikiran yang diajukan adalah: 
Ani Suhartini \& Saiful Anwar_Analisis Portofolio Pembiayaan Di Perbankan Syariah Yang Memiliki Risiko Pembiayaan Terkecil (Studi Kasus Bank BNI Syariah)

Posisi Kredit per Sektor

Ekonomi Bank Umum Syariah

a. Pertanian, Perburuan dan Kehutanan

b. Perikanan

c. Pertambangan dan Penggalian

d. Industri Pengolahan

e. Listrik, Gas, dan Air

f. Konstruksi

g. Perdagangan Besar dan Eceran

h. Penyediaan Akomodasi \& Penyediaan Makan Minum

i. Transportasi, Pergudangan, dan Komunikasi

j. Jasa Kemasyarakatan, Sosial Budaya, Hiburan

Kombinasi Sektor Ekonomi yang memiliki risiko kredit terkecil 


\section{METODE PENELITIAN}

Jenis data yang digunakan dalam penelitian ini adalah data sekunder. Data dalam penelitian ini mencakup data-data bulanan posisi pembaiayaan 10 (sepuluh) sektor ekonomi Perbankan di Indonesia berdasarkan kategori-kategori bank periode tahun 2013-2016. Data yang diambil adalah data dari posisi pembiayaan sepuluh sektor ekonomi perbankan di Indonesia selama periode tersebut, dimana sektor ekonomi yang tersedia pada Bank Indonesia terbagi atas sepuluh sektor. Kurun waktu yang digunakan selama tahun-tahun tersebut karena ingin melihat posisi pembaiayaan per sektor ekonomi Perbankan Syariah di Indonesia.

Data-data yang diperlukan dalam penelitian dikumpulkan dengan melakukan teknik dokumentasi, yaitu dengan mencatat atau mengcopy data yang tersedia pada dari Statistik Perbankan Bank Syariah serta data dari bagian lain di Bank Indonesia atau Otoritas Jasa Keuangan dan metode yang digunakan adalah metode sensus.

Teknik analisis Markowitz digunakan untuk melihat atau membandingkan kondisi rata-rata dan perkembangannya untuk melihat kecenderungan (profit). Model Markowitz menggunakan asumsi-asumsi sebagai berikut (Jogianto, 2003):

a. Waktu yang digunakan hanya satu periode

b. Tidak ada biaya transaksi

c. Preferensi investor hanya didasarkan pada return ekspektasi dan risiko dari portofolio

d. Tidak ada pinjaman dan simpanan bebas risiko

Asumsi bahwa preferensi investor hanya didasarkan pada return ekspektasi dan risiko dari portofolio secara implisit menganggap bahwa investor mempunyai fungsi utility yang sama. Pada kenyataannya tiap-tiap investor mempunyai utility yang berbeda. Jika preferensi investor terhadap portofolio berbeda, optimal portofolio untuk masing-masing investor akan dapat berbeda (Jogianto, 2003). 


\section{PEMBAHASAN}

Langkah awal dalam pengolahan data adalah melakukan perhitungan rata-rata NPF yang ditimbulkan dari pembiayaan yang diberikan per sektor ekonomi. Yaitu dengan membagi seluruh jumlah pembiayaan yang diberikan dengan jumlah NPF yang muncul dari pembiayaan tersebut. Dapat digunakan fungsi average padasoftware microsoft excel dengan argument tiap-tiap NPF seluruh periode penelitian, maka diperoleh rata-rata NPF per sektor ekonomi.

Langkah pengolahan selanjutnya adalah melakukan perhitungan risiko (standard deviation) pada seluruh periode penelitian untuk tiap-tiap sektor ekonomi. Risiko merupakan akar dari varian, jadi perhitungan resiko sejalan dengan menghitung varian. Dapat digunakan fungsi stdevp pada software microsoft excel dengan argument tiap-tiap NPF seluruh periode penelitian, maka diperoleh resiko per sektor ekonomi.

NPF diperoleh dengan melakukan perhitungan rata-rata dari NPF selama periode penelitian. Dari perhitungan tersebut sektor ekonomi Pertanian, Kehutanan, dan Sarana Pertanian memberikan tingkat NPF yang paling besar yaitu sebesar $8.32 \%$. Sedangkan prosesntase NPF terendah adalah sebesar $0.87 \%$ dari sektor ekonomi Jasa-Jasa Sosial Masyarakat. 
Ani Suhartini \& Saiful Anwar_Analisis Portofolio Pembiayaan Di Perbankan Syariah Yang Memiliki Risiko Pembiayaan Terkecil (Studi Kasus Bank BNI Syariah)

Tabel 2. Standar Deviasi dan NPF (dalam \%)

\begin{tabular}{|c|c|c|}
\hline Sektor Ekonomi & Standar Deviasi & $\begin{array}{c}\text { Rata-rata } \\
\text { NPF }\end{array}$ \\
\hline $\begin{array}{l}\text { Pertanian, kehutanan dan sarana } \\
\text { pertanian }\end{array}$ & 6,677 & $8.32 \%$ \\
\hline Pertambangan & 2,845 & $0.97 \%$ \\
\hline Industri Pengolahan & 7,384 & $1.67 \%$ \\
\hline Listrik, Gas \& Air & 1,945 & $1.92 \%$ \\
\hline Konstruksi & 6,107 & $7.65 \%$ \\
\hline Pedagangan, Restoran dan Hotel & 15,988 & $4.40 \%$ \\
\hline $\begin{array}{l}\text { Pengangkutan, Pergudangan, dan } \\
\text { Komunikasi }\end{array}$ & 2,157 & $3.91 \%$ \\
\hline Jasa-Jasa Dunia Usaha & 27,205 & $1.58 \%$ \\
\hline Jasa-Jasa Sosial Masyarakat & 8,684 & $0.87 \%$ \\
\hline Lain-Lain & 79,134 & $1.95 \%$ \\
\hline
\end{tabular}

Dari tabel 4.2 di atas dapat dilihat bahwa korelasi antar sektor ekonomi adalah berkisar $-0.6426<p<0.6690$. Tidak ada satu sektor ekonomi berkorelasi positif semua terhadap instrument lainnya, seperti pada sektor ekonomi pertanian, kehutanan, dan sarana pertanian berkorelasi positif terhadap sektor ekonomi pertambangan, listrik, gas \& air, perdagangan, restoran, dan hotel, jasa-jasa dunia usaha dan lain-lain. Tetapi pertanian, kehutanan, dan sarana pertanian berkorelasi negatif terhadap Industri pengolahan sebesar -0.1377, konstruksi sebesar 0.5302, pengangkutan, pergudangan, dan komunikasi sebesar -0.3778 dan Jasa-jasa sosial masyarakat sebesar -0.1327.

Sektor ekonomi pertanian, kehutanan, dan sarana pertanian berkorelasi negatif terhadap industri pengolahan, pengangkutan, pergudangan, dan komunikasi dan jasa-jasa sosial masyarakat. Artinya imbal hasil sektor ekonomi pertanian, kehutanan dan sarana pertanian bergerak berkebalikan atau bertolak belakang terhadap sektor ekonomi 
tersebut di atas. Hal ini dapat saja terjadi karena pertanian, kehutanan dan sarana pertanian tidak terkait secara langsung dengan sektor ekonomi industri pengolahan, pengangkutan, pergudangan, dan komunikasi dan jasa-jasa sosial masyarakat.

Dapat dilihat pada korelasi sektor ekonomi konstruksi sebesar 0.6426, artinya bahwa jika NPF sektor ekonomi konstruksi mengalami peningkatan satu satuan unit maka NPF sektor ekonomi listrik, gas \& air akan mengalami penurunan 0.6426 satu satuan unit. Dan jika NPF sektor ekonomi konstruksi mengalami penurunan satu satuan unit maka NPF sektor ekonomi listrik, gas \& air cenderung akan naik sebesar 0.6426 satu satuan unit.

Dengan mengetahui karakteristik korelasi seperti di atas, bank dapat menyusun strategi diversifikasi portofolio pembiayaan yang dimiliki untuk mengurangi resiko.Kovarians adalah suatu ukuran absolut yang menunjukkan sejauh mana return dari dua sekuritas dalam portofolio cenderung untuk bergerak secara bersama-sama.Kovarians dalam arti praktis dapat diartikan sebagai tingkat pengembalian kedua aktiva berbeda atau berubah secara bersamaan. Kovarians positif berarti pengembalian kedua aktiva cenderung bergerak atau berubah ke arah yang sama, sedangkan kovarians negatif berarti pengembalian bergerak pada arah yang berlawanan. Kovarians dapat dianggap sebagai korelasi antara pengembalian yang diharapkan dari kedua aktiva.

Dalam konteks manajemen portofolio, kovarians menunjukkan sejauhmana return dari dua sekuritas mempunyai kecenderungan bergerak bersama-sama. Mengestimasi return dan risiko portofolio berarti menghitung return yang diharapkan dan risiko suatu kumpulan aset individual yang dikombinasikan dalam suatu portofolio aset.

Kovarians adalah hubungan linier antar beberapa variabel diantaranya :

1. Positif berarti hubungan linier positif

2. Negatif berarti hubungan linier negatif

3. Nilai mendekati 0 berarti tidak ada hubungan linier 
Langkah selanjutnya dalam perhitungan pada penelitian ini adalah melakukan perhitungan kovarians (covariance) seluruh sektor ekonomi. Kovarians merupakan ukuran dari seberapa banyak dua set data yang berbeda-beda. Kovarians menentukan sejauh mana dua variable yang berkaitan atau bagaimana mereka bervariasi bersama. Kovarians merupakan rata-rata hasil dari penyimpangan dari titik data masingmasing mean. Dengan mengetahui kovarians dan korelasi antar sektor ekonomi, bank dapat mengetahui komposisi pembiayaan untuk mendapatkan portofolio yang optimal dengan resiko yang minimal dan NPF yang minim.Karena sektor ekonomi yang dipakai dalam penelitian ini adalah sepuluh sektor ekonomi maka persamaan untuk menemukan varian menjadi cukup panjang dan kompleks.Varian dari seluruh sektor ekonomi dihitung dengan bantuan fungsi perkalian pada software microsoft excel. Varian portofolio dihitung dalam spreadsheet dengan susunan matriks yang dirancang sedemikian rupa agar persamaan yang panjang dan komplek dapat dihitung dan disajikan dengan lebih mudah.

Dari tabel tersebut di atas diketahui bahwa portofolio per sektor ekonomi BNI Syariah yang memiliki resiko terkecil diperoleh apabila BNI Syariah menitikberatkan pemberian pembiayaan pada sektor ekonomi industri pengolahan dengan varians sebesar 2.5001 dari portofolio pembiayaan BNI Syariah dengan posisi pembiayaan rata-rata sebesar Rp. 576,234.

\section{SIMPULAN}

Pada penelitian kali ini penulis melakukan penelitian berdasarkan 10 sektor ekonomi yang telah dijelaskan sebelumnya. Hasil perhitungan berdasarkan teori portofolio Markowitz dimana dalam pembentukan portofolio para investor berusaha memaksimalkan pengembalian yang diharapkan dari investasi dengan tingkat resiko tertentu yang dapat diterima dan dengan tercapainya tujuan tersebut maka akan diperoleh portofolio yang efesien. Portofolio yang efesien adalah portofolio yang 
memiliki resiko terkecil. Berdasarkan pengolahan data pada bab-bab sebelumnya dapat disimpulkan bahwa Bank BNI Syariah akan memiliki pembiayaan yang optimal apabila memperbesar portofolio pembiayaannya pada sektor ekonomi Industri Pengolahan.

\section{DAFTAR PUSTAKA}

Badan Sertifikasi Manajemen Risiko, 2007

Beste, Allison, Dennis Leventhal, etc, 2002. The Markowitz Model:Selecting an Efficient Investment Portfolio, Lafayette College,Mathematics REU Program

Fabozzi, Frank. J.1999. Manajemen Investasi (Buku Satu), Salemba Empat, Jakarta

Ghozali, Imam M.Com, Akt, 2007. Manajemen Risiko PerbankanPendekatan Value at Risk., Badan Penerbit Universitas Diponegoro Semarang

Ghozali, Imam M.Com, Akt, 2001. Aplikasi Analisis Multivariate dengan Program SPSS., Badan Penerbit Universitas Diponegoro Semarang Jacobs, Bruce. I, Kenneth N. Levy, dan Harry Markowitz, 2005. Portofolio Optimization with Factors, Scenarios, and Realistic Short Positions, Operation Research Vol 53 No. 4 July-August, pp.586-599

Jogianto, Akt, 2003. Teori Portfolio dan Analisis Investasi, BPFEYogyakarta

Kamdem, Jules Kadefo, 2004. Value at Risk and Espected Shortfall for Linear Portfolios With Elliptically Distribute Risk Factors, International Journal of Theoretical and Applied Finance, World Scientific PublishingCompany

Mahmoeddin, AS. 2010. Melacak Kredit Bermasalah. Jakarta: Pustaka Sinar Harapan.

Mudjarat, Kuncoro. 2002. Manajemen Perbankan. Yogyakarta: BPFE Muhammad. 2005. Manajemen Bank Syariah.Yogyakarta: UPP AMP YKPN. 
Pass, Christopher, Byran Lones, Andrew Pendleton \& Leslie Chadwick, 1994. Collins: Kamus Lengkap Bisnis Edisi Kedua, Erlangga

Reilly, Frank K., Keith C. Brown, 2000. Sixth Edition: Investment Analysis and Portfolio Management, The Dryden Press, Harcourt College Publisher, Harcourt Inc

Sartono, R.Agus, Sri Zulaihati, 1998. Rasionalitas Investor Terhadap Pemilihan Saham dan Penentuan Portorfolio Optimal Dengan Model Indeks Tunggal di BEJ, Kelola No. 17/VII

Saunders, David, Costas Xiouros, Stavros A. Zenios, 2006. Credit Risk Optimizing Using Factor Models, Department of Statistics and Actuarial Science,University of Waterloo, Ontario, Canada

Soemarso, S.R, dkk, 1995. Kamus Keuangan, Penerbit Rineka Cipta Sugiyono, 2013. Metode Penelitian Bisnis, Alfabeta, Bandung

--------, 1989. Kamus Besar Bahasa Indonesia, Departemen Pendidikan dan Kebudayaan, Balai Pustaka

--------, 1959 . Markowitz, Harry, Portofolio Selection: The Rand Corporation

--------, 2005. Portfolio Diversification and Risk Analysis, Ontario Power Authority.

--------, 2007. Indonesia Certificate in Banking Risk and Regulation, Workbook Tingkat 1, Global Association of Risk Professionals, Badan SertifikasiManajemen Risiko

--------, 2007. Statistik Ekonomi Keuangan Daerah Jawa Tengah, Bank Indonesia,

Ismail, 2013. Perbankan Syariah. Penerbit Kencana Prenada Media Group : Jakarta. 
Lampiran 1. Hasil Korelasi

\begin{tabular}{|c|c|c|c|c|c|c|c|c|c|c|}
\hline $\begin{array}{c}\text { Korel } \\
\text { asi }\end{array}$ & 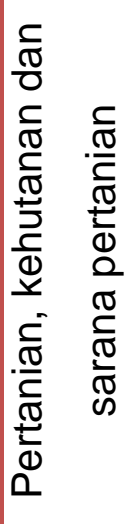 & 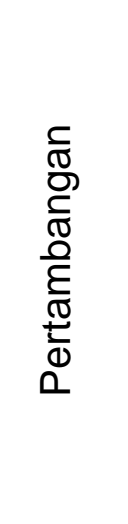 & 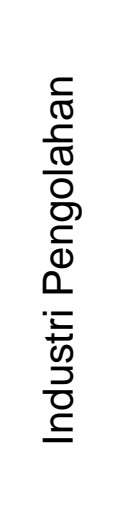 & 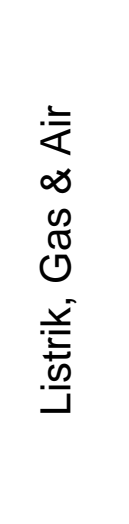 & 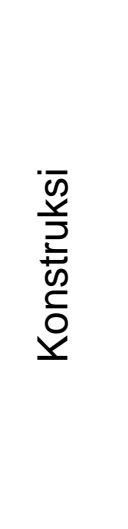 & 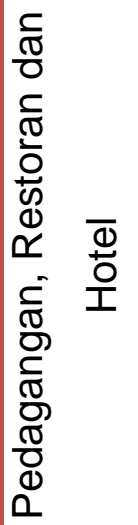 & 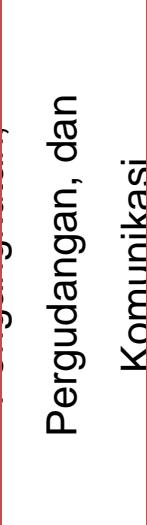 & 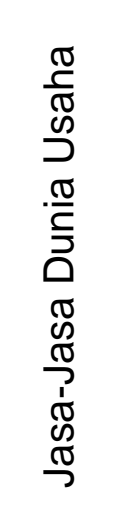 & 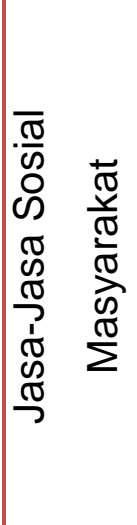 & 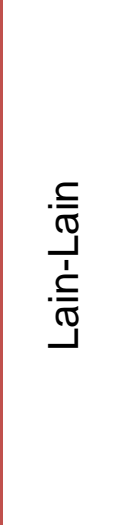 \\
\hline 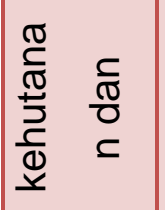 & 1 & $\begin{array}{c}0.586 \\
3\end{array}$ & $\begin{array}{c}- \\
0.137 \\
7\end{array}$ & $\begin{array}{c}0.424 \\
7\end{array}$ & $\begin{array}{c}- \\
0.530 \\
2\end{array}$ & $\begin{array}{c}0.597 \\
5\end{array}$ & $\begin{array}{c}0.377 \\
8\end{array}$ & $\begin{array}{c}0.357 \\
7\end{array}$ & $\begin{array}{c}- \\
0.132 \\
7\end{array}$ & $\begin{array}{c}0.429 \\
3\end{array}$ \\
\hline 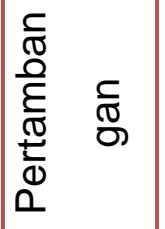 & $\begin{array}{c}0.586 \\
3\end{array}$ & 1 & $\begin{array}{c}0.049 \\
7\end{array}$ & $\begin{array}{c}0.421 \\
0\end{array}$ & $\begin{array}{c}- \\
0.587 \\
0\end{array}$ & $\begin{array}{c}0.669 \\
0\end{array}$ & $\begin{array}{c}- \\
0.117 \\
1\end{array}$ & $\begin{array}{c}0.092 \\
5\end{array}$ & $\begin{array}{c}- \\
0.098 \\
8\end{array}$ & $\begin{array}{c}0.516 \\
2\end{array}$ \\
\hline $\begin{array}{l}\frac{\pi}{\frac{\pi}{\pi}} \\
\frac{\pi}{0} \\
\frac{5}{0} \\
0\end{array}$ & $\begin{array}{c}- \\
0.137 \\
7\end{array}$ & $\begin{array}{c}0.049 \\
7\end{array}$ & 1 & $\begin{array}{c}0.275 \\
7\end{array}$ & $\begin{array}{c}- \\
0.431 \\
7\end{array}$ & $\begin{array}{c}0.010 \\
8\end{array}$ & $\begin{array}{c}- \\
0.035 \\
1\end{array}$ & $\begin{array}{c}- \\
0.129 \\
3\end{array}$ & $\begin{array}{c}- \\
0.149 \\
4\end{array}$ & $\begin{array}{c}- \\
0.350 \\
4\end{array}$ \\
\hline 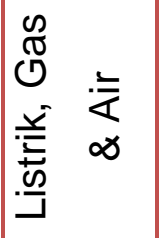 & $\begin{array}{c}0.424 \\
7\end{array}$ & $\begin{array}{c}0.421 \\
0\end{array}$ & $\begin{array}{c}0.275 \\
7\end{array}$ & 1 & $\begin{array}{c}0.642 \\
6\end{array}$ & $\begin{array}{c}0.401 \\
0\end{array}$ & $\begin{array}{c}0.245 \\
0\end{array}$ & $\begin{array}{c}0.144 \\
4\end{array}$ & $\begin{array}{c}0.098 \\
6\end{array}$ & $\begin{array}{c}0.172 \\
8\end{array}$ \\
\hline 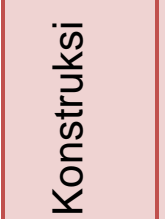 & $\begin{array}{c}- \\
0.530 \\
2\end{array}$ & $\begin{array}{c}- \\
0.587 \\
0\end{array}$ & $\begin{array}{c}- \\
0.431 \\
7\end{array}$ & $\begin{array}{c}- \\
0.642 \\
6\end{array}$ & 1 & $\begin{array}{c}- \\
0.486 \\
8\end{array}$ & $\begin{array}{c}0.369 \\
3\end{array}$ & $\begin{array}{c}- \\
0.125 \\
1\end{array}$ & $\begin{array}{c}- \\
0.033 \\
3\end{array}$ & $\begin{array}{c}- \\
0.281 \\
9\end{array}$ \\
\hline 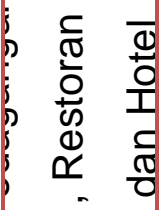 & $\begin{array}{c}0.597 \\
5\end{array}$ & $\begin{array}{c}0.669 \\
0\end{array}$ & $\begin{array}{c}0.010 \\
8\end{array}$ & $\begin{array}{c}0.401 \\
0\end{array}$ & $\begin{array}{c}- \\
0.486 \\
8\end{array}$ & 1 & $\begin{array}{c}- \\
0.123 \\
8\end{array}$ & $\begin{array}{c}0.295 \\
8\end{array}$ & $\begin{array}{c}- \\
0.045 \\
9\end{array}$ & $\begin{array}{c}0.601 \\
9\end{array}$ \\
\hline
\end{tabular}


Ani Suhartini \& Saiful Anwar_Analisis Portofolio Pembiayaan Di Perbankan Syariah Yang Memiliki Risiko Pembiayaan Terkecil (Studi Kasus Bank BNI Syariah)

\begin{tabular}{|c|c|c|c|c|c|c|c|c|c|c|}
\hline 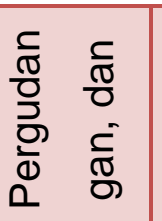 & $\begin{array}{c}0.377 \\
8\end{array}$ & $\begin{array}{c}0.117 \\
1\end{array}$ & $\begin{array}{c}- \\
0.035 \\
1\end{array}$ & $\begin{array}{c}0.245 \\
0\end{array}$ & $\begin{array}{c}0.369 \\
3\end{array}$ & $\begin{array}{c}0.123 \\
8\end{array}$ & 1 & $\begin{array}{c}0.338 \\
4\end{array}$ & $\begin{array}{c}0.204 \\
7\end{array}$ & $\begin{array}{c}- \\
0.085 \\
0\end{array}$ \\
\hline 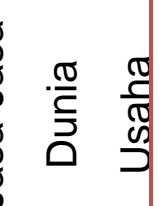 & $\begin{array}{c}0.357 \\
7\end{array}$ & $\begin{array}{c}0.092 \\
5\end{array}$ & $\begin{array}{c}- \\
0.129 \\
3\end{array}$ & $\begin{array}{c}- \\
0.129 \\
3\end{array}$ & $\begin{array}{c}- \\
0.125 \\
1\end{array}$ & $\begin{array}{c}0.295 \\
8\end{array}$ & $\begin{array}{c}- \\
0.338 \\
4\end{array}$ & 1 & $\begin{array}{c}0.178 \\
0\end{array}$ & $\begin{array}{c}0.124 \\
4\end{array}$ \\
\hline 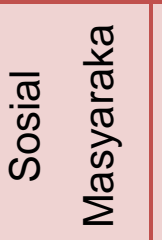 & $\begin{array}{c}- \\
0.132 \\
7\end{array}$ & $\begin{array}{c}- \\
0.098 \\
8\end{array}$ & $\begin{array}{c}- \\
0.149 \\
4\end{array}$ & $\begin{array}{c}0.098 \\
6\end{array}$ & $\begin{array}{c}- \\
0.033 \\
3\end{array}$ & $\begin{array}{c}- \\
0.045 \\
9\end{array}$ & $\begin{array}{c}- \\
0.295 \\
7\end{array}$ & $\begin{array}{c}0.178 \\
0\end{array}$ & 1 & $\begin{array}{c}- \\
0.007 \\
5\end{array}$ \\
\hline 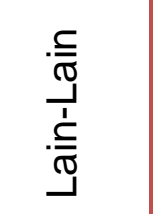 & $\begin{array}{c}0.429 \\
3\end{array}$ & $\begin{array}{c}0.516 \\
2\end{array}$ & $\begin{array}{c}- \\
0.350 \\
4\end{array}$ & $\begin{array}{c}0.172 \\
8\end{array}$ & $\begin{array}{c}0.281 \\
9\end{array}$ & $\begin{array}{c}0.601 \\
9\end{array}$ & $\begin{array}{c}- \\
0.085 \\
0\end{array}$ & $\begin{array}{c}0.124 \\
4\end{array}$ & $\begin{array}{c}- \\
0.007 \\
5\end{array}$ & 1 \\
\hline
\end{tabular}


Lampiran 2. Kovarian Instrument (dalam \%)

\begin{tabular}{|c|c|c|c|c|c|c|c|c|c|c|}
\hline $\begin{array}{l}\bar{y} \\
\frac{\pi}{0} \\
\overline{0} \\
\overline{\underline{\alpha}}\end{array}$ & 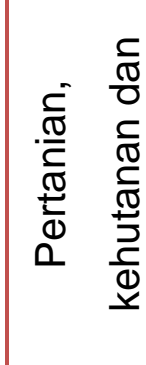 & 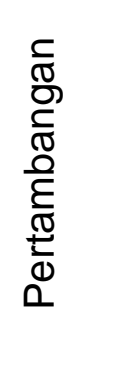 & 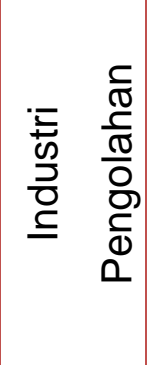 & 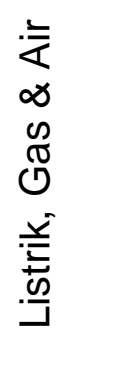 & 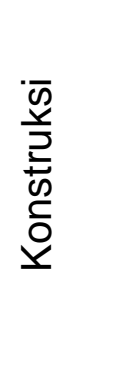 & 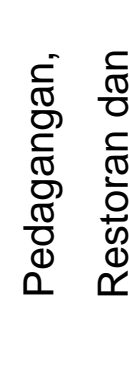 & 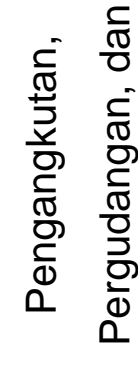 & 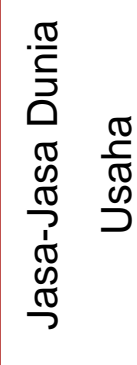 & 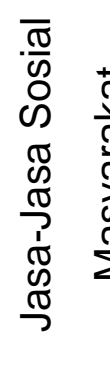 & 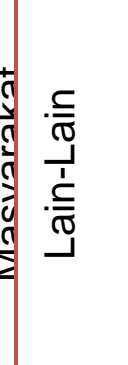 \\
\hline 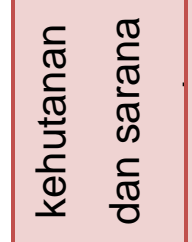 & $\begin{array}{c}0.002 \\
4\end{array}$ & $\begin{array}{c}0.000 \\
2\end{array}$ & $\begin{array}{c}- \\
0.000 \\
1\end{array}$ & $\begin{array}{c}0.000 \\
4\end{array}$ & $\begin{array}{c}- \\
0.001 \\
4\end{array}$ & $\begin{array}{c}0.000 \\
6\end{array}$ & $\begin{array}{c}- \\
0.000 \\
7\end{array}$ & $\begin{array}{c}0.000 \\
2\end{array}$ & $\begin{array}{c}0.00 \\
00\end{array}$ & $\begin{array}{c}0.00 \\
01\end{array}$ \\
\hline 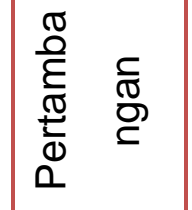 & $\begin{array}{c}0.000 \\
2\end{array}$ & $\begin{array}{c}0.000 \\
1\end{array}$ & $\begin{array}{c}0.000 \\
0\end{array}$ & $\begin{array}{c}0.000 \\
1\end{array}$ & $\begin{array}{c}0.000 \\
3\end{array}$ & $\begin{array}{c}0.000 \\
1\end{array}$ & $\begin{array}{c}0.000 \\
0\end{array}$ & $\begin{array}{c}0.000 \\
0\end{array}$ & $\begin{array}{c}0.00 \\
00\end{array}$ & $\begin{array}{c}0.00 \\
00\end{array}$ \\
\hline 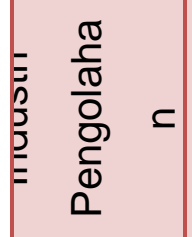 & $\begin{array}{c}- \\
0.000 \\
1\end{array}$ & $\begin{array}{c}0.000 \\
0\end{array}$ & $\begin{array}{c}0.000 \\
1\end{array}$ & $\begin{array}{c}0.000 \\
0\end{array}$ & $\begin{array}{c}0.000 \\
2\end{array}$ & $\begin{array}{c}0.000 \\
0\end{array}$ & $\begin{array}{c}0.000 \\
0\end{array}$ & $\begin{array}{c}0.000 \\
0\end{array}$ & $\begin{array}{c}0.00 \\
00\end{array}$ & $\begin{array}{c}0.00 \\
00\end{array}$ \\
\hline 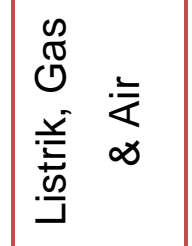 & $\begin{array}{c}0.000 \\
4\end{array}$ & $\begin{array}{c}0.000 \\
1\end{array}$ & $\begin{array}{c}0.000 \\
0\end{array}$ & $\begin{array}{c}0.000 \\
5\end{array}$ & $\begin{array}{c}- \\
0.000 \\
8\end{array}$ & $\begin{array}{c}0.000 \\
2\end{array}$ & $\begin{array}{c}- \\
0.000 \\
2\end{array}$ & $\begin{array}{c}0.000 \\
0\end{array}$ & $\begin{array}{c}0.00 \\
00\end{array}$ & $\begin{array}{c}0.00 \\
00\end{array}$ \\
\hline $\begin{array}{l}\bar{w} \\
\text { 竞 } \\
\bar{w} \\
\bar{c} \\
\overline{0}\end{array}$ & $\begin{array}{c}- \\
0.001 \\
4\end{array}$ & $\begin{array}{c}0.000 \\
3\end{array}$ & $\begin{array}{c}0.000 \\
2\end{array}$ & $\begin{array}{c}0.000 \\
8\end{array}$ & $\begin{array}{c}0.003 \\
0\end{array}$ & $\begin{array}{c}- \\
0.000 \\
6\end{array}$ & $\begin{array}{c}0.000 \\
7\end{array}$ & $\begin{array}{c}- \\
0.000 \\
1\end{array}$ & $\begin{array}{c}0.00 \\
00\end{array}$ & $\begin{array}{c}0.00 \\
01\end{array}$ \\
\hline 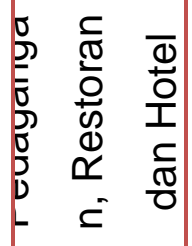 & $\begin{array}{c}0.000 \\
6\end{array}$ & $\begin{array}{c}0.000 \\
1\end{array}$ & $\begin{array}{c}0.000 \\
0\end{array}$ & $\begin{array}{c}0.000 \\
2\end{array}$ & $\begin{array}{c}- \\
0.000 \\
6\end{array}$ & $\begin{array}{c}0.000 \\
4\end{array}$ & $\begin{array}{c}- \\
0.000 \\
1\end{array}$ & $\begin{array}{c}0.000 \\
1\end{array}$ & $\begin{array}{c}0.00 \\
00\end{array}$ & $\begin{array}{c}0.00 \\
00\end{array}$ \\
\hline 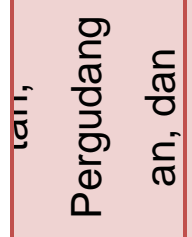 & $\begin{array}{c}- \\
0.000 \\
7\end{array}$ & $\begin{array}{c}0.000 \\
0\end{array}$ & $\begin{array}{c}0.000 \\
0\end{array}$ & $\begin{array}{c}- \\
0.000 \\
2\end{array}$ & $\begin{array}{c}0.000 \\
7\end{array}$ & $\begin{array}{c}- \\
0.000 \\
1\end{array}$ & $\begin{array}{c}0.001 \\
3\end{array}$ & $\begin{array}{c}- \\
0.000 \\
2\end{array}$ & $\begin{array}{c}0.00 \\
00\end{array}$ & $\begin{array}{c}0.00 \\
00\end{array}$ \\
\hline
\end{tabular}


Ani Suhartini \& Saiful Anwar_Analisis Portofolio Pembiayaan Di Perbankan Syariah Yang Memiliki Risiko Pembiayaan Terkecil (Studi Kasus Bank BNI Syariah)

\begin{tabular}{|c|c|c|c|c|c|c|c|c|c|c|}
\hline 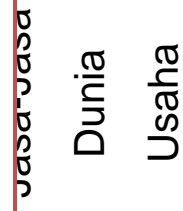 & $\begin{array}{c}0.000 \\
2\end{array}$ & $\begin{array}{c}0.000 \\
0\end{array}$ & $\begin{array}{c}0.000 \\
0\end{array}$ & $\begin{array}{c}0.000 \\
0\end{array}$ & $\begin{array}{c}0.000 \\
1\end{array}$ & $\begin{array}{c}0.000 \\
2\end{array}$ & $\begin{array}{c}0.000 \\
2\end{array}$ & $\begin{array}{c}0.000 \\
2\end{array}$ & $\begin{array}{c}0.00 \\
00\end{array}$ & $\begin{array}{c}0.00 \\
00\end{array}$ \\
\hline 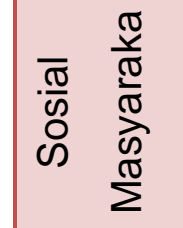 & $\begin{array}{c}0.000 \\
0\end{array}$ & $\begin{array}{c}0.000 \\
0\end{array}$ & $\begin{array}{c}0.000 \\
0\end{array}$ & $\begin{array}{c}0.000 \\
0\end{array}$ & $\begin{array}{c}0.000 \\
0\end{array}$ & $\begin{array}{c}0.000 \\
0\end{array}$ & $\begin{array}{c}0.000 \\
0\end{array}$ & $\begin{array}{c}0.000 \\
0\end{array}$ & $\begin{array}{c}0.00 \\
00\end{array}$ & $\begin{array}{c}0.00 \\
00\end{array}$ \\
\hline 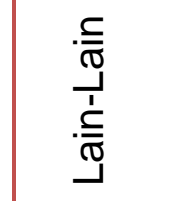 & $\begin{array}{c}0.000 \\
1\end{array}$ & $\begin{array}{c}0.000 \\
0\end{array}$ & $\begin{array}{c}0.000 \\
0\end{array}$ & $\begin{array}{c}0.000 \\
0\end{array}$ & $\begin{array}{c}0.000 \\
1\end{array}$ & $\begin{array}{c}0.000 \\
0\end{array}$ & $\begin{array}{c}0.000 \\
0\end{array}$ & $\begin{array}{c}0.000 \\
0\end{array}$ & $\begin{array}{c}0.00 \\
00\end{array}$ & $\begin{array}{c}0.00 \\
00\end{array}$ \\
\hline
\end{tabular}


Ani Suhartini \& Saiful Anwar_Analisis Portofolio Pembiayaan Di Perbankan Syariah Yang Memiliki Risiko Pembiayaan Terkecil (Studi Kasus Bank BNI Syariah)

Lampiran 3. Varians Instrument(\%)

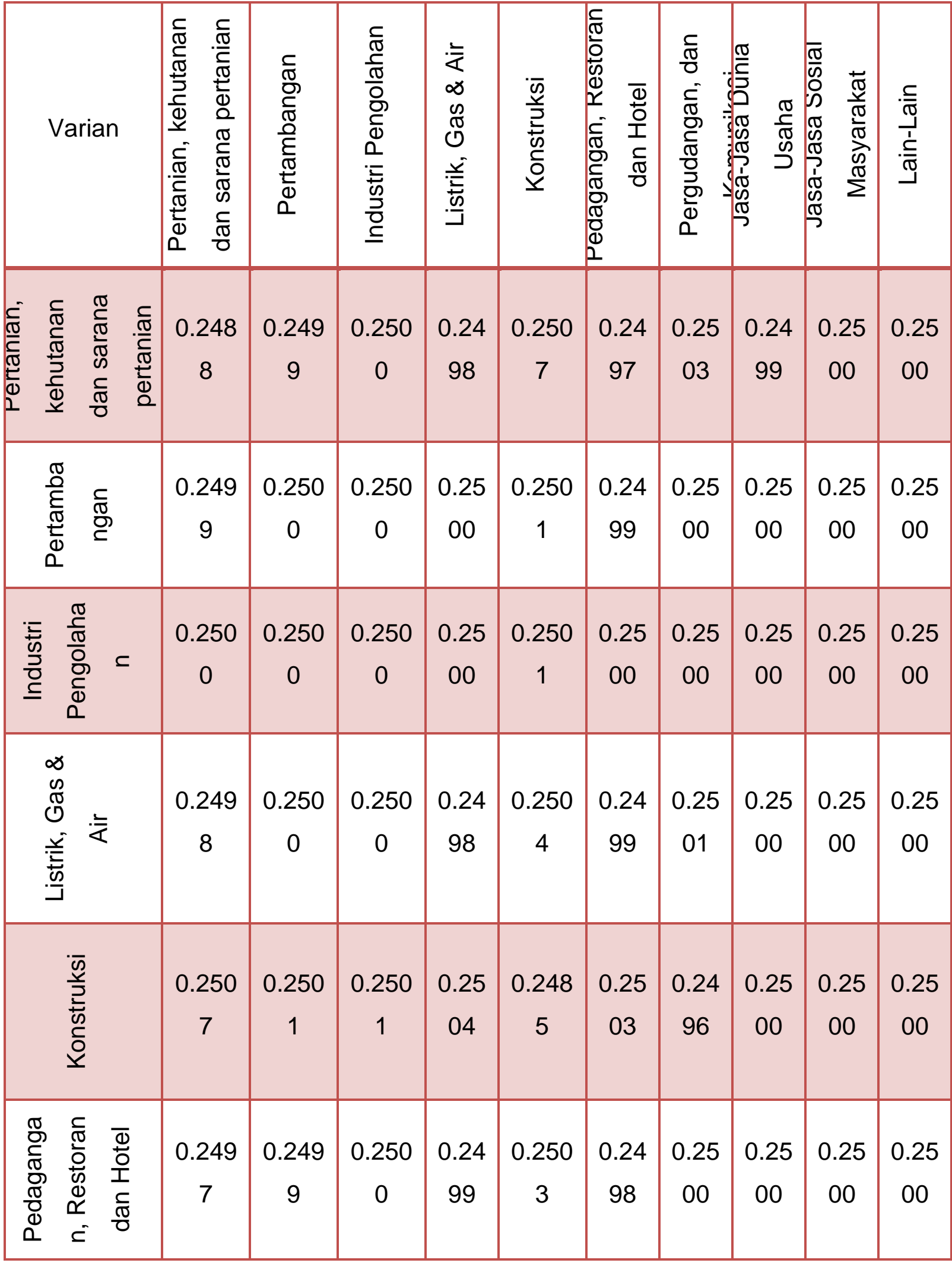


Ani Suhartini \& Saiful Anwar_Analisis Portofolio Pembiayaan Di Perbankan Syariah Yang Memiliki Risiko Pembiayaan Terkecil (Studi Kasus Bank BNI Syariah)

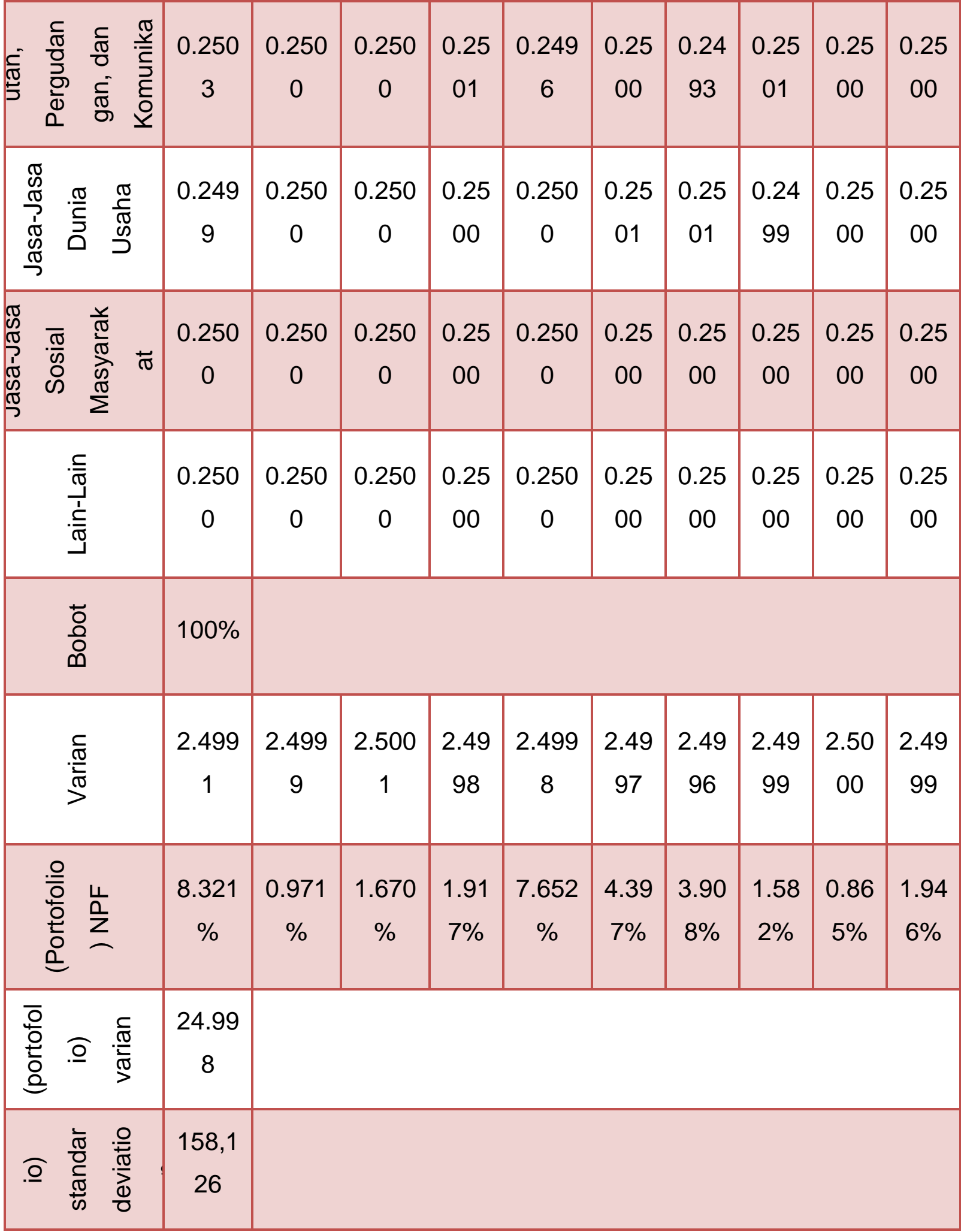

